\title{
Effect of Combined Application of FYM, Fly Ash and Fertilizers on Soil Properties and Paddy Grown on Degraded Land
}

\author{
BHARAT LAL ${ }^{1}$, VINOD NAYAK ${ }^{2}$, PRIYANKA SHARMA ${ }^{3}$ and K. TEDIA ${ }^{4}$ \\ ${ }^{1} P G$ Student, Department of Soil Science and Agricultural Chemistry, IGKV , Raipur, India. \\ ${ }^{2,3}$ SRF, Department of Soil Science and Agricultural Chemistry, IGKV, Raipur, India. \\ ${ }^{4}$ Principal Scientist, Department of Soil Science and Agricultural Chemistry, IGKV , Raipur, India.
}

http://dx.doi.org/10.12944/CWE.9.2.38

(Received: June 12, 2014; Accepted: August 14, 2014)

\begin{abstract}
A field study was carried out on a sandy loam soil at the KVK farm Janjgir Champa , Chhattisgarh to study the effect of enriched fly ash (FA) on rice and soil characteristics of inceptisol during kharif 2013-14. The test crop was rice var. MTU-1010. The application of different treatment FA combinations increased paddy yield compared to $100 \%$ GRD. However the control treatment failed to produce the yield in degraded land. Among the treatments, the $75 \%$ GRD +60 FAha $^{-1}+5 t$ FYMha $^{-1}$ gave highest paddy yield $\left(42.6 \mathrm{q} \mathrm{ha}^{-1}\right)$ than all other treatments. The straw yield was not significantly influenced by FA treatments, but the beneficial effect of enriched fly ash on higher rice straw yield was observed. Application of $75 \%$ GRD + fly ash@ $60 \mathrm{t} \mathrm{ha}^{-1}+$ FYM @ $5 \mathrm{t} \mathrm{ha}^{-1}$ recorded the highest soil available phosphorus, potassium and zinc compared to other treatments and soilavailable $\mathrm{N}$ was highest in application of 75\% GRD + fly ash@ $40 \mathrm{th \textrm {h } ^ { - 1 }}+\mathrm{FYM} @ 5 \mathrm{t} \mathrm{ha}^{-1}$. The soilavailable $\mathrm{Cu}, \mathrm{Mn}$ and Fe content were not significantly influenced by different combination of FYM, FA and Fertilizers. The organic carbon storage on degraded land increased significantly with the application $75 \%$ GRD + fly ash@ $60 \mathrm{t} \mathrm{ha}^{-1}+$ FYM @ $5 \mathrm{t} \mathrm{ha}^{-1}\left(6043.33 \mathrm{~kg} \mathrm{ha}^{-1}\right)$ than the $100 \%$ GRD and control .
\end{abstract}

Key words : Fly ash, FYM, Rice, Soil properties, Yield.

\section{INTRODUCTION}

Coal is a predominant source of global energy; at present in India it is major source of electrical energy in thermal power plants, which produce 175 million tonnes per year fly ash, which would require about 40,000 hectares of land for the construction of ash ponds (Lal et al., 2012). Fly ash an amorphous ferroalumino silicate, Physically fly ash occurs as fine particles ( $60-70 \%)$ with a size below $0.075 \mathrm{~mm}$ is a by product of pulverized coal fired thermal power station low to medium bulk density, high surface area and very light texture with $\mathrm{pH}$ ranged from 4.5 to 12 depending upon S content in the coal ( Lal et al., 2012). It can act as a secondary source of fertilizer nutrients like $\mathrm{P}, \mathrm{K}, \mathrm{Ca}, \mathrm{Mg}, \mathrm{S}, \mathrm{Cu}$,
$\mathrm{Fe}, \mathrm{Zn}, \mathrm{Mn}, \mathrm{Mo}$ etc. (Totawat et al., 2002). Fly ash increased the yield in various crops by $20-25 \%$ with high nutritional value and found beneficial for soil and crop when fly ash was applied on soil $>10 \%$ by weight (Yavarzadeh et al., 2012). Hence, an experiment was conducted with the objective to find out the effect of enriched fly ash on soil health, growth and yield in degraded land.

\section{MATERIALS AND METHODS}

A field experiment was conducted in a sandy loam soil at the KVK Research Farm, Janjgir Champa,Chhattisgarh during the kharifse as on, 2013-14. The experiment design was randomized block design comprised of eight 
treatment combinations with three levels of fly ash $\left(20,40\right.$ and $\left.60 \mathrm{t} \mathrm{ha}^{-1}\right)$ and two levels of FYM ( 0 and $\left.5 \mathrm{tha}^{-1}\right)$.

Fly ash and FYM applied as per the treatments before transplanting the rice. All the plots received the 75 percent of general recommended dose (GRD)of NPK fertilizers (100-60-40 kg ha-1) except control and 100 percent GRD. Thericevar .MTU-1010 was used as the test crop. The fly ashwas collected from Madhya Bharat Paper Ltd. Village - Birgahni Champa Dist.- Janjgir Champa ,Chhattisgarh . The nutrient contents of used FYM and Fly ash applied in the experiment was given in Table 1.

Table 1: Chemical properties of FYM and FA used in experiment

\begin{tabular}{lcc}
\hline Particulars & FYM & FA \\
\hline Organic carbon (\%) & 5.07 & 0.36 \\
$\mathrm{~N} \mathrm{( \% )}$ & 0.92 & 0.084 \\
$\mathrm{P}(\%)$ & 0.239 & 0.043 \\
$\mathrm{~K}(\%)$ & 0.361 & 0.33 \\
$\mathrm{Fe}(\%)$ & 0.55 & 0.73 \\
$\mathrm{Mn} \mathrm{( \% )}$ & 0.12 & 0.016 \\
$\mathrm{Zn} \mathrm{( \% )}$ & 0.009 & 0.007 \\
$\mathrm{Cu}(\%)$ & 0.005 & 0.003 \\
\hline
\end{tabular}

$\mathrm{FYM}=$ Farm Yard Manure, $\mathrm{FA}=$ Fly ash
The effect of different treatments was evaluated in terms of soil available major and micro nutrients at crop harvest and the crop yield. Available nitrogen was estimated by alkaline potassium permanganate method (Subbaiah and Asija, 1956). Available phosphorus content was extracted by Olsen'sreagent and determined by ascorbic acid method (Watanabe and Olsen, 1965). Available potassium was extracted by using neutral normal ammonium acetate (Muhr et al.,1965) and determined by flame photometer. Organic carbon was determined by Walkley and Black rapid titration method as described by Piper (1957) and storage calculate $0-10 \mathrm{~cm}$ depth of soil with having bulk density. Available micronutrients (DTPA extractable) $\mathrm{Fe}, \mathrm{Mn}$, Cuand $\mathrm{Zn}$ were analyzed by DTPA method using atomic absorption spectrophotometer (Lindsayand Norvell, 1978).

\section{RESULTS AND DISCUSSION}

The soil belongs to sandy loam texture and the soil status was low in available nitrogen , phosphorus and high in potassium (Table 3). The soil available micronutrients were above the critical limits except for Zn (Table 4). The control plots failed to produce the yield due to very low $\mathrm{N}$ and $\mathrm{P}$ status of soil (fig. 1 and Table 2, 3).The application of different treatment combinations except $75 \%$ GRD +20 t Fly ash ha ${ }^{-1}$ with and without FYM increased

Table 2: Effect of combined application of FYM , FA and fertilizers on grain and straw yield of rice

\begin{tabular}{|c|c|c|}
\hline Treatments & $\begin{array}{l}\text { Grain yield } \\
\left(q \text { ha }^{-1}\right)\end{array}$ & $\begin{array}{c}\text { Straw yield } \\
\left(q \mathrm{ha}^{-1}\right)\end{array}$ \\
\hline$T_{1}-$ Control & 0.00 & 10 \\
\hline$T_{2}^{1}-100 \%$ GRD (100:60:40) & 31.67 & 47.50 \\
\hline $\mathrm{T}_{3}^{2}-75 \% \mathrm{GRD}+20 \mathrm{t} \mathrm{FA} \mathrm{ha-1}$ & 26.83 & 44.83 \\
\hline $\mathrm{T}_{4}^{3}-75 \%$ GRD +40 t FA ha-1 & 33.67 & 46.33 \\
\hline $\mathrm{T}_{5}^{4}-75 \%$ GRD +60 t FA ha-1 & 31.83 & 41.50 \\
\hline $\mathrm{T}_{6}^{5}-75 \%$ GRD +20 t FA ha- ${ }^{-1}+5 \mathrm{t} \mathrm{FYM} \mathrm{ha}^{-1}$ & 28 & 47 \\
\hline $\mathrm{T}_{7}^{6}-75 \%$ GRD +40 t FA ha-1 $+5 \mathrm{t} \mathrm{FYM} \mathrm{ha}^{-1}$ & 37.67 & 49.42 \\
\hline $\mathrm{T}_{8}-75 \%$ GRD +60 t FA ha-1 +5 t FYM ha-1 & 42.67 & 51.50 \\
\hline SEm \pm & 2.05 & 1.74 \\
\hline C.D. $(P=0.05)$ & 6.22 & 5.30 \\
\hline
\end{tabular}

$F A=$ fly ash, $F Y M=$ farm yard manure and $G R D=$ general recommended dose of $\mathrm{N}, \mathrm{P}$ and $\mathrm{K}$ 
the grain yield compared to General recommended dose (GRD). The highest grain yield (42.6 q ha-1) was recorded by application of $75 \%$ GRD $+60 t$
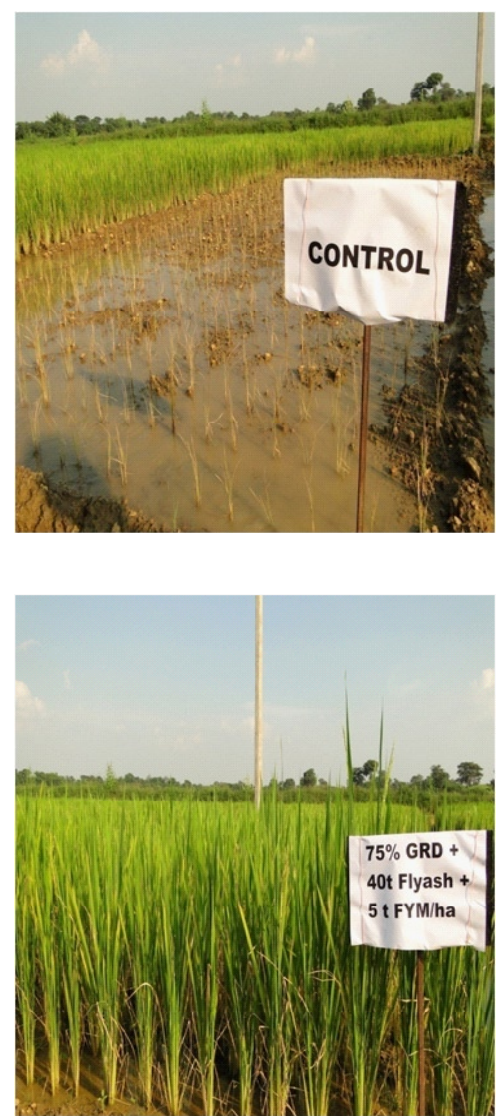

FAha $^{-1}+5$ t FYMha $^{-1}$, which was at par with $75 \%$ GRD+ $40 \mathrm{t} \mathrm{FAha}^{-1}+5 \mathrm{t} \mathrm{FYMha}^{-1}$. Thus application of fly ash not only increased the paddy yield by $30 \%$

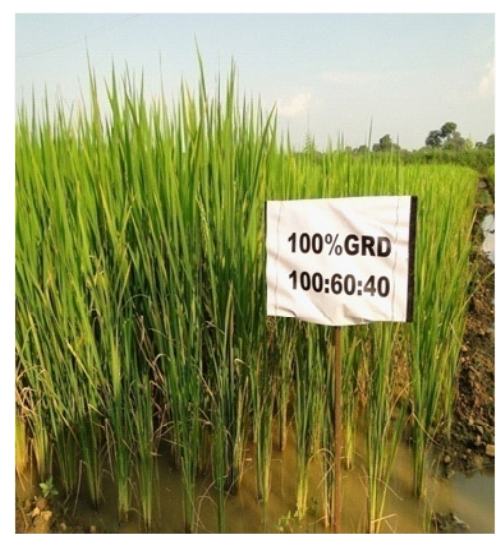

Fig. 1 : Effect of different fly ash treatments on crop growth

Table 3 :Effect of combined application of FYM , FA and fertilizers on available major nutrients and organic carbon storage of soil at harvest.

\begin{tabular}{|c|c|c|c|c|}
\hline \multirow[t]{2}{*}{ Treatments } & \multicolumn{3}{|c|}{ Available major nutrients ( $\mathrm{kg} \mathrm{ha}^{-1}$ ) } & \multirow{2}{*}{$\frac{\text { sOC Storage }}{\mathrm{C}\left(\mathrm{kg} \mathrm{ha}^{-1}\right)}$} \\
\hline & Nitrogen & Phosphorus & Potassium & \\
\hline$T_{1}$ - Control & 109 & 0.74 & 550.36 & 5045.33 \\
\hline $\mathrm{T}_{2}-100 \%$ GRD (100:60:40) & 135.89 & 1.16 & 580.49 & 5188.67 \\
\hline $\mathrm{T}_{3}-75 \%$ GRD +20 t FA ha $^{-1}$ & 135.89 & 1.28 & 562.01 & 5457.33 \\
\hline $\mathrm{T}_{4}-75 \%$ GRD +40 t FA ha-1 & 137.98 & 1.43 & 576.57 & 5346.67 \\
\hline $\mathrm{T}_{5}-75 \%$ GRD +60 t FA ha- ${ }^{-1}$ & 133.80 & 1.22 & 565.37 & 4728.00 \\
\hline $\mathrm{T}_{6}-75 \%$ GRD +20 tFA ha ${ }^{-1}+5 \mathrm{t} \mathrm{FYM} \mathrm{ha}^{-1}$ & 137.98 & 1.28 & 569.93 & 5484.00 \\
\hline $\mathrm{T}_{7}^{0}-75 \%$ GRD $+40 \mathrm{tFA} \mathrm{ha}^{-1}+5 \mathrm{t} \mathrm{FYM} \mathrm{ha}^{-1}$ & 139.89 & 1.37 & 600.06 & 5776.33 \\
\hline $\mathrm{T}_{8}-75 \%$ GRD $+60 \mathrm{tFA} \mathrm{ha}^{-1}+5 \mathrm{t} \mathrm{FYM} \mathrm{ha}^{-1}$ & 137.80 & 1.52 & 616.09 & 6043.33 \\
\hline initial & 107.40 & 0.80 & 549.81 & 4710 \\
\hline SEm \pm & 2.13 & 0.043 & 12.03 & 126.22 \\
\hline C.D. $(P=0.05)$ & 6.46 & 0.13 & 36.5 & 382.84 \\
\hline
\end{tabular}


Table 4 : Effect of combined application of FYM , FA and fertilizers on available micronutrients

\begin{tabular}{lcccc}
\hline \multirow{2}{*}{ Treatments } & \multicolumn{4}{c}{ Soil available micronutrients $\left(\mathbf{m g ~ k g}^{-1}\right)$} \\
\cline { 2 - 5 } & Iron & Manganese & Zinc & Copper \\
\hline T1 - Control & 7.63 & 8.35 & 0.70 & 0.38 \\
T2 - 100\% GRD (100:60:40) & 8.63 & 9.11 & 0.74 & 0.39 \\
T3 - 75\% GRD + 20 t FA ha-1 & 9.43 & 10.61 & 0.82 & 0.56 \\
T4 - 75\% GRD + 40 t FA ha-1 & 9.86 & 10.94 & 1.21 & 0.82 \\
T5 - 75\% GRD + 60 t FA ha-1 & 8.74 & 10.20 & 1.13 & 0.52 \\
T6 - 75\% GRD + 20 t FA ha-1 + 5t FYM ha-1 & 9.63 & 9.71 & 1.24 & 0.62 \\
T7 - 75\% GRD + 40 tFA ha-1 + 5 t FYMha-1 & 10.07 & 11.77 & 1.30 & 0.90 \\
T8 - 75\% GRD + 60 t FA ha-1 +5 t FYMha-1 & 11.02 & 12.75 & 1.42 & 0.92 \\
Initial & 8.09 & 9.72 & 0.68 & 0.43 \\
SEm \pm & 0.79 & 1.04 & 0.12 & 0.13 \\
C.D. ( P = 0.05) & NS & NS & 0.38 & NS \\
& & & & \\
\hline
\end{tabular}

but also saved the $25 \%$ of NPK fertilizer. The straw yield was significantly higher in different treatments over control and further combinationof fly ash with or without FYM was found similar to GRD but showed at most $8.42 \%$ increased in straw yield. The supply of nutrients, conductive to physical environment leading to better aeration, root activity and nutrient absorption and the consequent complementary effect by fly ash application with organic and inorganic fertilizer would have resulted in higher grain and straw yield of rice this finding are in conformity with that of Reddy et al .,(2010) . The beneficial effect of fly ash on yield was also reported by Aggarwal et al.(2009) in wheat and sorghum and by Arivazhagan et al. (2011) in rice, wheat, maize, ragi.

An increase in soil available major and micronutrients status ondegraded soil was observed (Table 3 and 4). The soil available $\mathrm{N}$ status was significantly higher by the application of the treatments over control. The soil test Phosphorus was significantly higher under the combined treatment over 100\% GRD and control, the treatments 75\% GRD + 60t FAha ${ }^{-1}+5$ FYM ha $^{-1}$ and $75 \%$ GRD +40 t FAha $^{-1}+5$ t FYMha $^{-1}$ showed higher soil test $P$ compared to GRD. Similarly in different FA combination treatments $75 \%$ GRD + 60t FAha ${ }^{-1}+5$ FYM ha $^{-1}$ and 75\% GRD + 40 t FAha $^{-1}$ $+5 \mathrm{t} \mathrm{FYMha-10ver} \mathrm{GRD} \mathrm{showed} \mathrm{higher} \mathrm{available} \mathrm{K}$ status in soil, further the fly ash when combined with organic and chemical fertilizer showed remarkable increase in soil available K over $100 \%$ GRD. The organic carbon storage was increased with the combination of treatments and was maximum in $75 \%$ GRD + 60t FAha-1 + 5t FYM ha-1 $\left(6063.33 \mathrm{~kg} \mathrm{ha}^{-1}\right)$ as compare to GRD and control .

The application of $75 \%$ GRD + 60 t FAha $^{-1}$ $+5 \mathrm{t} \mathrm{FYMha}{ }^{-1}$ has recorded higher available $\mathrm{Zn}$ as compare to $100 \%$ GRD and control (Table 4). The $\mathrm{Fe}, \mathrm{Mn}$ and $\mathrm{Cu}$ content was not influenced by the different combination of treatments.

The increase in soil available major nutrients status due to fly ash application was reported by Khanet al. (2008) and Ramet al. (2011) the increase in available major nutrients except $\mathrm{K}$ concluded by Dey et al. (2012). The organic carbon was increased application of FA and FYM reported by Karmakar et al., (2009). The beneficial effect of fly ash on improvement of soil health in respect of physico-chemical parameters, nutritional status and microbial population may be due to the cumulative effect of improvement in individual physico-chemical characteristics (Yeledhalli et al.,2008).

\section{ACKNOWLEDGEMENT}

The authors are grateful to the Head and advisor Department of Soil Science and Agricultural Chemistry, College of Agriculture, IGKV, Raipur for providing Laboratory facilities and co-operation of Krishi Vigyan Kendra, Janjgir Champa is also acknowledged. 


\section{REFERENCES}

1. Lal, K., Chhabra, R., Mongia A.D. , Meena, R.L.and Yadav, R.K. Release and uptake of potassium and sodium with fly ash application in rice on reclaimed alkali soil . J. Indian Soci. of Soil Sci.60 : 181-186 (2012) .

2. Tatawat, K.L., Nagar, G.L., Jat, S.L. and Jangir, R. K. In : Symposium on effect of fly ash on the performance of wheat on ustochrepts of sub - humid plains of India , held during 14-21 August 2002 , Thailand, Symposium no. 24 , paper no. 215, pp 1-11 (2002).

3. Yavarzadeh, M.R. and Shamsadini, H. Safe environment by using fly ash and vermicompost on wheat. In : International conference on transport, environment and civilengineering, held during 25-26 August 2012 at Kuala Lumpur (Malaysia), pp 146-148 (2012).

4. Reddy, T.P., Umadevi , M and Rao, P.C. Effect of fly ash and farm yard manure on soil properties and yield of rice grown on an inceptisol. Agric. Sci. Digest., 30(4) : 281 285 (2010).

5. Aggarwal, S., Singh, G.R and Yadav, B.R. Utilization of fly ash for crop production : Effect on the growth of wheat and Sorghum Crops and soil properties. J. Agril. Physics 9, 20-23 (2009) .

6. Arivazhagan, K., Ravichandran, M., Dube, S.K., Mathur, V.K., Khandakar, R.K., Yagnanarayana, K., Pasha, M.M.K. Sinha, A.K., Sarangi , B.D., Tripathi, V.K.M., Gupta, S.K., Singh, R., Ali, M., Thakur, A.S. and
Narayan , R. Effect of coal fly ash on agriculture crops: show case project on use of fly ash in Agriculture in and around Thermal power station area of national thermal power corporation Ltd., India. World of Coal Ash (WOCA) Conference- May 9- 12 , 2011, in Denver, CO, USA (2011) .

7. Khan, M.J. and Qasim, M. Integrated use of boiler ash as organic fertilizer and soil conditioner with NPK in calcareous soil . Songklanakarin J. Sci. Tech. 30 (3): 281-289 (2008).

8. Ram, L.C., Masto, R.E., Singh, S., Tripathi, R.C., Jha, S.K., Srivastava,N.K., Sinha, A.K .,Selvi, V.A. and Sinha, A. An Appraisal of Coal Fly Ash Soil Amendment Technology (FASAT) of Central Institute of Mining and Fuel Research (CIMFR). World Aca . of Sci., Engi. And Tech. 52 : 703-714 (2011).

9. Dey , B.S., Panigrahi, S., Panigrahi, T. and Panda, R.B. Agricultural utilization of fly ash - a way for sustainable agriculture practice and its environmental significance.Discovery Nature1 (1) : 11-14 (2012).

10. Karmakar, S., Mittra, B.N. and Ghosh, B.C. Influence of Industrial Solid Wastes on SoilPlant Interaction in Rice Under Acid Lateritic Soil. World of Coal Ash (WOCA) Conference held May 4 -7 , 2009 in Lexington , KY ,USA (2009).

11. Yeledhalli, N.A., Prakash, S.S., Ravi, M.V. and Narayanarao, K. Long term effect of fly ash on crop yield and soil properties. Kar. j. of Agric. Sci. 21 (4) : 507-512 (2008). 